\title{
Correlation between DNA/HSA-interactions and antimalarial activity of acridine derivatives: Proposing a possible mechanism of action
}

\author{
Marina de M. Silva ${ }^{\mathrm{a}}$, Taís S. Macedo ${ }^{\mathrm{b}}$, Helena Mariana P. Teixeira ${ }^{\mathrm{b}}$, Diogo Rodrigo M. Moreira ${ }^{\mathrm{b}}$, \\ Milena B.P. Soares ${ }^{\mathrm{b}, \mathrm{c}}$, Ana Ligia da C. Pereira ${ }^{\mathrm{d}}$, Vanessa de L. Serafim ${ }^{\mathrm{d}}$, \\ Francisco J.B. Mendonça-Júnior ${ }^{\mathrm{d}}$, Maria do Carmo A. de Lima ${ }^{\mathrm{e}}$, Ricardo O. de Moura ${ }^{\mathrm{d}}$, \\ Edeildo F. da Silva-Júnior ${ }^{\mathrm{a}, \mathrm{f}}$, João Xavier de Araújo-Júnior ${ }^{\mathrm{a}, \mathrm{f}}$, Maria Dayanne de A. Dantas ${ }^{\mathrm{a}}$, \\ Eduarda de O. O. Nascimento ${ }^{a}$, Thamilla Maria S. Maciel ${ }^{a}$, Thiago Mendonça de Aquino ${ }^{a}$, \\ Isis M. Figueiredo ${ }^{a}$, Josué C.C. Santos ${ }^{a}$,

\footnotetext{
a Instituto de Química e Biotecnologia, Universidade Federal de Alagoas, Campus A.C. Simões, 57072-900 Maceió, AL, Brazil

b Centro de Pesquisas Gonçalo Moniz, Fundação Oswaldo Cruz, 40296-710 Salvador, BA, Brazil

${ }^{\mathrm{c}}$ Centro de Biotecnologia e Terapia Celular, Hospital São Rafael, 41253-190 Salvador, BA, Brazil

d Laboratório de Síntese e Vetorização de Moléculas, Departamento de Ciências Biológicas, Universidade Estadual da Paraíba, $58071-160$ João Pessoa, PB, Brazil

e Departamento de Antibióticos, Laboratório de Planejamento e Síntese de Fármacos, Universidade Federal de Pernambuco, $50670-901$ Recife, PE, Brazil
} \\ ${ }^{\mathrm{f}}$ Laboratório de Química Medicinal, Escola de Enfermagem e Farmácia, Universidade Federal de Alagoas, 57072-970, Macéio, AL, Brazil
}

\section{A R T I C L E I N F O}

\section{Keywords:}

Acridines

Antimalarial activity

Calf thymus DNA and HSA interaction

Activity-interaction correlation

\begin{abstract}
A B S T R A C T
Acridines are considered an important class of compounds due to their wide variety of biological activities. In this work, we synthesized four acridine derivatives (1-4) and evaluated their biological activity against the Plasmodium falciparum W2 line, as well as studied the interaction with ctDNA and HSA using spectroscopic techniques and molecular docking. The acridine derivative $2\left(\mathrm{IC}_{50}=0.90 \pm 0.08 \mu \mathrm{M}\right)$ was more effective against $P$. falciparum than primaquine $\left(\mathrm{IC}_{50}=1.70 \pm 0.10 \mu \mathrm{M}\right)$ and similar to amsacrine $\left(\mathrm{IC}_{50}=0.80 \pm 0.10 \mu \mathrm{M}\right)$. In the fluorescence and UV-vis assays, it was verified that the acridine derivatives interact with ctDNA and HSA leading to a nonfluorescent supramolecular complex formation. The non-covalent binding constants ranged from 2.09 to $7.76 \times 10^{3} \mathrm{M}^{-1}$, indicating moderate interaction with ctDNA. Through experiments with KI, fluorescence contact energy transfer and competition assays were possible to characterize the main non-covalent binding mode of the acridines evaluated with ctDNA as intercalation. The binding constants obtained showed a high linear correlation with the $\mathrm{IC}_{50}$ values against the antimalarial activity, suggesting that DNA may be the main biological target of these molecules. Finally, HSA interaction studies were performed and all evaluated compounds bind to the site II of the protein. The less active compounds ( 1 and $\mathbf{3})$ presented the highest affinity to HSA, indicating that the interaction with carrier protein can affect the (bio)availability of these compounds to the biological target.
\end{abstract}

\section{Introduction}

Acridines are heterocyclic compounds derived from anthracenes, formed by two rings fused to a pyridine ring in a central position (Scheme 1), also known as dibenzo-pyridine, 10-azaantracen and 2,3dibenzoquinoline [1]. Different substitutions on the heterocyclic ring can confer several biological activities to the new derivatives such as antitumor, anti-convulsant, anti-malarial, anti-inflammatory and antimicrobial [1-3].

Due to these pharmacological properties, the synthesis of these compounds has been of considerable interest in medicinal chemistry [4]. Scheme 1 represents a compilation of some studies on synthetic acridine derivatives with different biological activities [5-8]. Some of these biological activities are in part related to the ability to interact with DNA since the preferential mechanism of some bioactive molecules has DNA as the main biological target. According to Giorgio et al. [9], it is well established that the planar structure of tricyclic rings on acridines is what gives the ability to interfere with a variety of metabolic processes in cells.

Acridines and its derivatives were the first chromophore groups

\footnotetext{
* Corresponding author.

E-mail address: josue@iqb.ufal.br (J.C.C. Santos).
} 


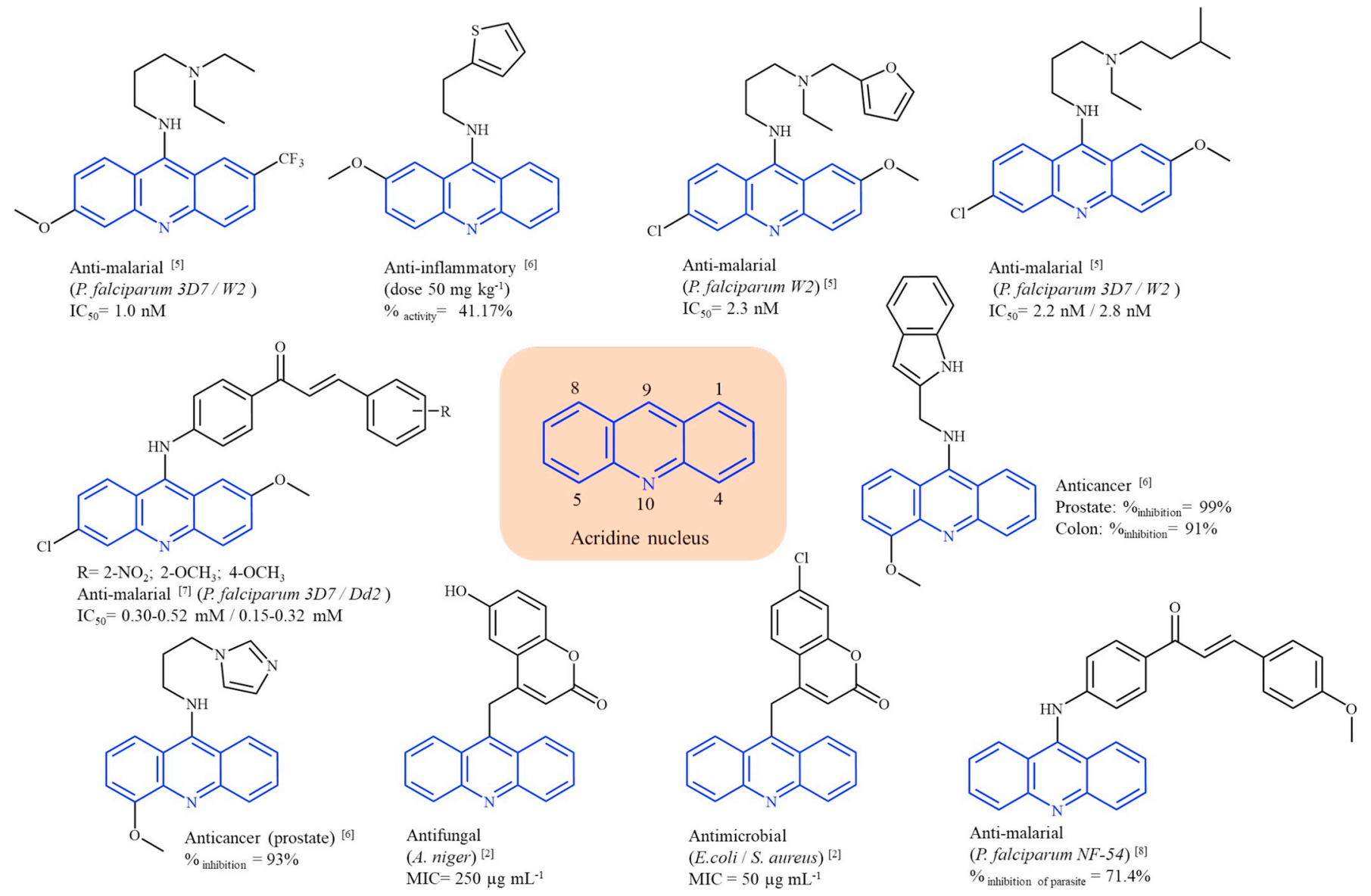

Scheme 1. Some acridines derivatives with biological activity.

widely used for studies of non-covalent interaction with DNA [10]. Due to its heteroaromatic planar structure, the non-covalent binding mechanism of these compounds occurs via intercalation, i.e., between the nucleic acid base pairs, affecting some biological functions and combating several diseases. Therefore, because of the properties exhibited by this class of compounds, they have been considered important candidates for drugs and widely exploited in several therapeutic applications, especially by owning potent antimalarial activity [11-13].

Among the neglected diseases, malaria is still considered one of the most frequent and frightening, being responsible for high rates of mortality and morbidity [14]. Malaria is caused by protozoan parasites of the genus Plasmodium, and the parasites are transmitted by mosquitoes of the genus Anopheles. The P. falciparum causes the most fatal malaria cases, due to the production of specific proteins that are transported and embedded in the cell membrane of the infected erythrocyte [15].

Although death from malaria has been considerably reduced over years, new studies on drug discovery need to focus on blocking disease transmission and targeting the liver-stage forms of the parasite to achieve disease elimination [16]. Over the last few years, acridine derivatives based on 9-aminoacridine and respective scaffolds have been reported for antimalarial activity, and its mechanism of action may be related to DNA intercalation, binding to heme and inhibition of the enzyme topoisomerase II [17].

In addition, to evaluate the acridines distribution mechanism to the target molecules in the organism, interaction studies with albumin, in particular, human serum albumin (HSA), can be carried out, since these proteins are abundant in the circulatory system and act as carriers of metabolites and xenobiotics. Therefore, the interaction study of small molecules with carrier proteins and nucleic acids provides information about the mechanism of action, pharmacokinetic and pharmacodynamic aspects of its (bio)availability [18].

Thus, in the present work, the anti- $P$. falciparum activity of four acridine derivatives was described, as well as, its affinity with ctDNA and HSA using spectroscopic techniques (UV-vis and fluorescence spectroscopy). In addition, molecular docking and TD-DFT studies were performed to corroborate the experimental results, by predicting the non-covalent binding mode as well as the relative binding energy of the complex formed between acridine derivatives and DNA.

\section{Results and Discussion}

\subsection{Chemistry}

The acridine derivatives were synthesized, initially, by an addition reaction between cyanoacethohydrazide and 6,9-dichloro-3-methoxyacridine, where the intermediate $\mathbf{1}$ obtained, after treatment with aromatic aldehydes, afforded the target compounds 2-4 (Scheme 2). The chemical structures were established using NMR, IR and high-resolution mass spectrometry (HRMS). The IR spectra of 1-4 showed absorption bands at about 1633-1628 and $1607-1466 \mathrm{~cm}^{-1}$ associated with $\mathrm{C}=\mathrm{C}$ stretching vibration and $\mathrm{C}=\mathrm{O}$ amide $\mathrm{I}$ band, respectively. In the ${ }^{1} \mathrm{H}$ NMR spectra of 2-4, the introduction of benzylidene groups was confirmed through the absence of the signal of $\mathrm{CH}_{2}$ group (4.11 ppm) characteristic of 1 , and the presence of resonance at $8.71 \mathrm{ppm}$ attributed to methine hydrogen. Additionally, analysis by ${ }^{13} \mathrm{C}$ NMR and HRMS confirm the acridine derivatives structure synthesized. The Fig. S1-S16 (supplementary material) present the complete characterization of the acridines derivatives synthesized. 
<smiles>[R]c1ccc(/C=C(\C#N)C(=O)NNc2c3ccc(Cl)cc3nc3ccc(OC)cc23)cc1</smiles>

Scheme 2. Reagents and conditions: (i) anhydrous $\mathrm{EtOH}, 70^{\circ} \mathrm{C}, 4 \mathrm{~h}$; (ii) aromatic aldehydes, anhydrous toluene, $110^{\circ} \mathrm{C}$, overnight.

\subsection{Antimalarial Activity Against P. falciparum}

The acridine derivatives evaluated in this study were tested for antimalarial activity against the chloroquine-resistant $P$. falciparum strain (W2), and the cytotoxic activity was analyzed using human hepatoma (HepG2) host cells since the liver is one of the main organs involved in the metabolism of these drugs. Moreover, from the ratio between the toxic dose to $50 \%$ of the cells and their activity anti-P. falciparum $\left(\mathrm{IC}_{50}\right.$ ), it was calculated the selectivity index (SI) that represents the relationship between the active dose and the toxic dose. In the biological assays, standard compounds were used: amsacrine (AMS), which presents structural similarity with the acridines evaluated in this work; mefloquine (MEF) and primaquine (PRM), which are known as antimalarial drugs. Results for these assays are shown in Table 1.

All synthesized compounds were active against $P$. falciparum W2 strain and were less cytotoxic than reference drugs against HepG2 cells. Acridine derivative $\mathbf{1}$ showed $\mathrm{IC}_{50}$ value against $P$. falciparum W2 strain 3.5 times lower than amsacrine. However, an introduction of benzylidene group unsubstituted led in corresponding compound 2, which showed IC $_{50}$ value comparable to amsacrine, and SI 14 times higher, indicating that the presence of a benzylidene group favors biological activity, reduces toxicity and increases cell selectivity. The presence of

Table 1

Results for the biological assays of the acridines evaluated against $P$. falciparum W2 strain and HepG2 positive control.

\begin{tabular}{llll}
\hline Compound & $\mathrm{IC}_{50} \pm s d(\mu \mathrm{M})$ & $\begin{array}{l}\text { Selectivity index } \\
(\mathrm{SI})\end{array}$ \\
\cline { 2 - 3 } & Cell line P. falciparum W2 & Host cells HepG2 & \\
\hline $\mathbf{1}$ & $2.80 \pm 0.08$ & $73.5 \pm 2.8$ & 26 \\
$\mathbf{2}$ & $0.90 \pm 0.08$ & $80.7 \pm 0.5$ & 90 \\
$\mathbf{3}$ & $3.20 \pm 0.20$ & $>200$ & $>62$ \\
$\mathbf{4}$ & $2.40 \pm 1.10$ & $>200$ & $>83$ \\
AMS & $0.80 \pm 0.10$ & $5.20 \pm 0.60$ & 6.5 \\
MEF & $0.04 \pm 0.01$ & $11.8 \pm 0.3$ & 295 \\
PRM & $1.70 \pm 0.10$ & $82.9 \pm 0.2$ & 49 \\
\hline
\end{tabular}

$s d=$ standard deviation. benzylidene group $p$-substituted carried no significant changes in the activity of $\mathbf{3}$ and $\mathbf{4}$ in comparison with $\mathbf{1}$. All compounds were also found less potent than mefloquine.

For comparison, in a similar study, a series of $\beta$-benzoylstyrene derivatives of acridine have been synthesized by Prajapati et al. [7] and all the compounds were screened for intraerythrocytic in vitro antimalarial activity against chloroquine-sensitive (3D7) and chloroquineresistant (Dd2) strains of $P$. falciparum using the SYBR green I fluorescence assay. Cytotoxicity study was performed against the HeLa cell line using the MTT assay. Compounds substituted with $2-\mathrm{NO}_{2}, 2-\mathrm{OCH}_{3}$ and $4-\mathrm{OCH}_{3}$ were the most potent with $\mathrm{IC}_{50}$ in the range of $0.30-0.52 \mu \mathrm{M}$ against the $3 \mathrm{D} 7$ and $0.15-0.32 \mu \mathrm{M}$ against the Dd2 strain.

In agreement with works published by Valdés et al. [19], various mechanisms have been proposed for acridines and acridinones with antimalarial activity. Inhibition of hemozoin ( $\beta$-hematin) formation, mitochondrial $b c 1$ complex, DNA topoisomerase II, and interaction with DNA are the widest studied. Thus, DNA interaction studies were performed in order to evaluate the possible mechanism of action of acridines 1-4.

\subsection{Interaction Studies of Acridines Derivatives with ctDNA}

The interaction studies of acridine derivatives with ctDNA were carried out using UV-vis and molecular fluorescence techniques, as well as molecular docking studies. Among the evaluated acridines derivatives, 2 showed the greatest biological activity against $P$. falciparum W2 cell line. Therefore, it was used as a model to present the results.

\subsubsection{Evaluation of Acridines Interaction Employing Fluorescence Spectroscopy}

In the evaluation of acridine derivatives (1-4) interaction with ctDNA, it was observed that all evaluated compounds present emission at $461 \mathrm{~nm}$ when excited between 280 and $295 \mathrm{~nm}$. Due to the intrinsic fluorescence of acridines, they were titrated with ctDNA, and was verified that by adding increasing amounts of the macromolecule to the system, there was a gradual decrease of the fluorescence intensity, related the concentration reduction of free acridine derivative in the solution [20]. The Fig. 1a shows the spectral profile obtained for 

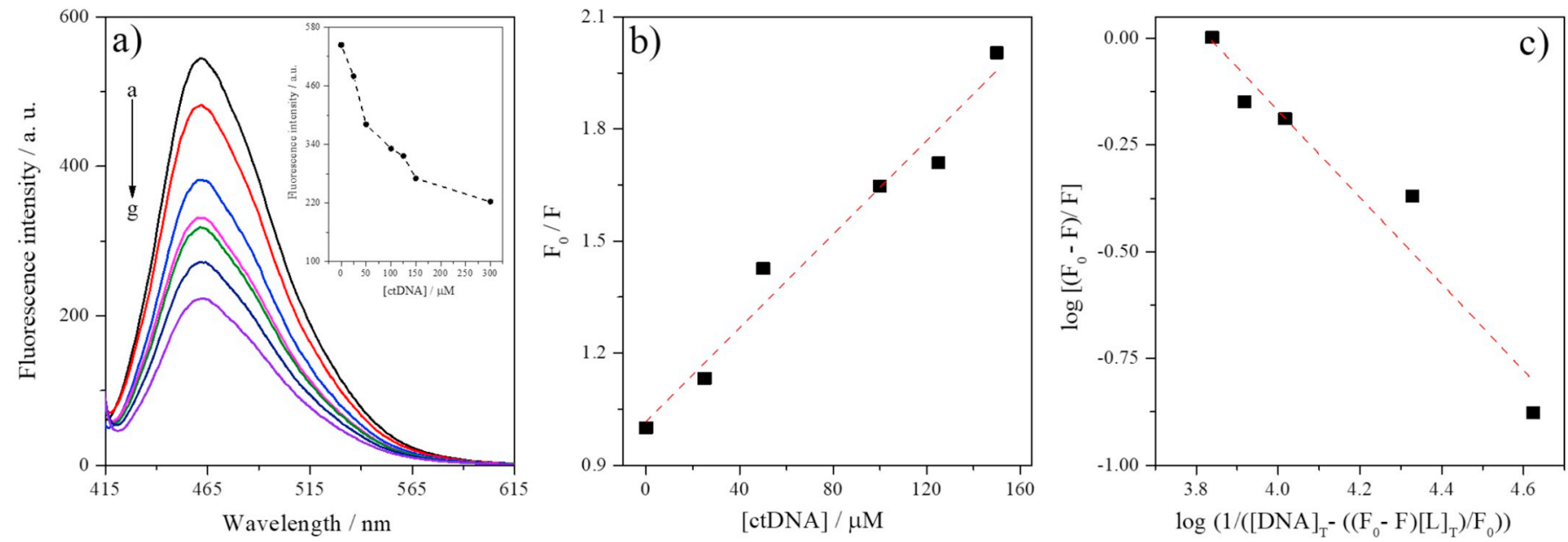

Fig. 1. a) Spectral profile of the acridine derivative $2(10 \mu \mathrm{M})$ with the addition of increasing amounts of ctDNA $(0,25,50,100,125,150$ and $300 \mu \mathrm{M}$, curves a-g respectively). The inset corresponds to profile of analytical signal saturation after DNA addition at acridine derivative 2. b) Stern-Volmer plot for 2 (quenching process); c) Double logarithmic curve of the non-covalent binding constant of 2 with ctDNA. Condition: $\mathrm{pH}=7.4$ (phosphate buffer) at $30^{\circ} \mathrm{C}$ and $20 \mathrm{mM}$ of ionic strength.

compound 2, being the saturation of the system observed from the ctDNA concentration of $150 \mu \mathrm{M}$. Similar behavior was observed for the other acridine derivatives evaluated.

The Stern-Volmer constant $\left(\mathrm{K}_{\mathrm{SV}}\right)$, non-covalent binding constant $\left(\mathrm{K}_{\mathrm{b}}\right)$ and the number of binding sites between the ligand and ctDNA were determined by spectrofluorometric titration. The Stern-Volmer constant was calculated using the following equation was used:

$\frac{\mathrm{F}_{0}}{\mathrm{~F}}=1+\mathrm{K}_{\mathrm{SV}}[\mathrm{Q}]$ or $\frac{\mathrm{F}_{0}}{\mathrm{~F}}=1+\mathrm{K}_{\mathrm{q}} \tau_{0}[\mathrm{Q}]$

where $F_{0}$ and $F$ are the fluorescence intensities in the absence and presence of ctDNA, respectively, while $\mathrm{K}_{\mathrm{q}}$ is the diffusional bimolecular quenching rate constant, $\tau_{0}$ is the average lifetime, typically $10^{-8} \mathrm{~s}$, [Q] is the ctDNA concentration (which acts as quencher) and $\mathrm{K}_{\mathrm{SV}}$ is the Stern-Volmer constant [21]. The non-covalent binding constant $\left(\mathrm{K}_{\mathrm{b}}\right)$ and the number of binding sites $(n)$ in the supramolecular complex formed between the evaluated acridine derivatives (ligands) and ctDNA were calculated:

$\log \left(\frac{\mathrm{F}_{0}-\mathrm{F}}{\mathrm{F}}\right)=n \log \mathrm{K}_{\mathrm{b}}+n \log \left(\frac{1}{[\operatorname{ctDNA}]_{\mathrm{T}}-\left(\frac{\mathrm{F}_{0}-\mathrm{F}}{\mathrm{F}_{0}}\right)[\mathrm{L}]_{\mathrm{T}}}\right)$

where $[\mathrm{L}]_{\mathrm{T}}$ is the total concentration of the ligand. The values of $\mathrm{K}_{\mathrm{b}}$ and $n$ are obtained from the curve $\log \left[\left(\mathrm{F}_{0}-\mathrm{F}\right) / \mathrm{F}\right]$ vs $\log \left[\left(1 /\left([\mathrm{ctDNA}]_{\mathrm{T}}\right)\right.\right.$ $\left.\left.\left(\left(F_{0}-F\right) \times[L]_{T}\right) / F_{0}\right)\right]$. The Fig. $1 b$ and $c$ present the profiles of the curves for compound $\mathbf{2}$ from the linearization of Eqs. (1) and (2), respectively. Table 2 presents the data for all compounds evaluated.

According to Savariz et al. [22], spectral changes qualitatively indicate the interaction between the evaluated compounds and ctDNA. However, the process of energy transfer from the ligand to the biomolecule (quenching) can be quantitatively evaluated based on the Stern-Volmer equation. Thus, according to Table 2, it was observed that $\mathrm{K}_{\mathrm{SV}}$ values ranged from 1.65 to $6.27 \times 10^{3} \mathrm{M}^{-1}$, indicating the decrease of the analytical signal in the presence of the suppressor agent (in this case the ctDNA) and that all acridines evaluated interacted with ctDNA.

The constant $\mathrm{K}_{\mathrm{q}}$ was evaluated to characterize the quenching mechanism in the interaction process between acridines and ctDNA. According to Das et al. [21] when the velocity constant is $<2.0$ $\times 10^{10} \mathrm{M}^{-1} \mathrm{~s}^{-1}$, the quenching will be preferentially dynamic, whereas for higher $\mathrm{K}_{\mathrm{q}}$ values static quenching is expected. The $\mathrm{K}_{\mathrm{q}}$ ranged from 1.65 to $6.27 \times 10^{11} \mathrm{M}^{-1} \mathrm{~s}^{-1}$, being higher than the limiting diffusional constant. Therefore, static quenching is the dominant, characterized by the formation of supramolecular complex non-fluorescent in the ground state. In addition, the ctDNA-acridine quenching mechanism was confirmed by UV-Vis studies, which are presented in the supplemental material.

To evaluate the magnitude of the ctDNA-acridine interaction, the values of the non-covalent binding constants $\left(\mathrm{K}_{\mathrm{b}}\right)$ were evaluated, which varied from 2.09 to $7.76 \times 10^{3} \mathrm{M}^{-1}$ for the acridines $1-4$. The $\mathrm{K}_{\mathrm{SV}}$ and $\mathrm{K}_{\mathrm{b}}$ values presented the same bias indicating that there was an agreement between these parameters associated with the quenching and interaction processes.

The $\mathrm{K}_{\mathrm{b}}$ values obtained were lower than the results found in the literature for other acridines, that presented constants of magnitude $10^{4}-10^{5} \mathrm{M}^{-1}$ [23-30], as shown in Scheme S1 (Supplementary material). These differences in $\mathrm{K}_{\mathrm{b}}$ values can be associated to several factors related to the experimental conditions used, such as type and concentration of the buffer and DNA, ionic strength, $\mathrm{pH}$ and concentration of acridines (Scheme S1). Besides, the characteristics of each technique employed to measure the non-covalent binding constants between the

Table 2

Interaction parameters of ctDNA with acridines derivatives 1-4. Condition: $\mathrm{pH}=7.4$ (phosphate buffer) at $30^{\circ} \mathrm{C}$ and $20 \mathrm{mM}$ of ionic strength.

\begin{tabular}{|c|c|c|c|c|c|c|c|}
\hline Compounds & \multicolumn{3}{|c|}{ Stern-volmer constant } & \multicolumn{3}{|c|}{ Binding parameters } & $\frac{\text { Thermodynamic parameters }}{\Delta \mathrm{G}\left(\mathrm{kJ} \mathrm{mol}^{-1}\right)^{\mathrm{a}}}$ \\
\hline 1 & $3.79 \pm 0.42$ & 0.9821 & 3.79 & $4.17 \pm 0.82$ & $0.99 \pm 0.18$ & 0.9690 & -20.6 \\
\hline 3 & $1.65 \pm 0.20$ & 0.9786 & 1.65 & $2.09 \pm 0.69$ & $1.02 \pm 0.16$ & 0.9750 & -18.9 \\
\hline 4 & $4.00 \pm 0.48$ & 0.9844 & 4.00 & $4.47 \pm 0.71$ & $0.98 \pm 0.16$ & 0.9729 & -20.8 \\
\hline
\end{tabular}

${ }^{a}$ The Gibbs free energy $(\Delta \mathrm{G})$ values were calculated according to the equation: $\Delta \mathrm{G}=-\mathrm{RT} \ln \left(\mathrm{K}_{\mathrm{b}}\right)$, where $\mathrm{T}$ is the temperature in Kelvin and $\mathrm{R}$ is the ideal gas constant. 
ligand-DNA must be considered. However, the substitution pattern proved to be a critical factor, since the acridines derivatives evaluated in this work are substituted in the $\mathrm{C} 9, \mathrm{C} 2$, and C6 carbon, whereas in other studies, the substitution occurs more frequently in C3 and C6 carbons (Scheme S1, compounds a-c).

The presence of nitrogen substituents facilitates the interaction process. Depending on the $\mathrm{pK}_{\mathrm{a}}$ of the group and the $\mathrm{pH}$ in which the experiments are conducted, the nitrogen substituents are susceptible to be protonated (Scheme S1, compounds a-f), generating a positive charge. Indeed, the positive nitrogen substituent in the compound leads to a greater interaction between the ligand and the DNA, since an additional non-covalent binding mode occurs, in this case, based on electrostatic interactions with phosphate groups of the backbone of DNA [31]. For the acridine derivatives 1-4 the $\mathrm{pK}_{\mathrm{a}}$ values and degree of ionization were calculated [32]. The theoretical $\mathrm{pK}_{\mathrm{a}}$ values ( 7.86 for $\mathbf{1}$ and 7.84 for 2-4) indicates that, for the acridine derivatives, the cationic forms $(\mathrm{pH}=7.4$.) were the preferential at $72.81 \%$ (1) and 74.13\% (2-4).

Compounds with additional interaction mode as ethidium bromide, acridine orange, DAPI, thiazole orange, Hoechst 33258, among others, which present positive charge in their structure in physiologic $\mathrm{pH}$, and strong DNA interaction. The compounds $\mathbf{g}-\mathbf{j}$ (Scheme S1), present $\mathrm{K}_{\mathrm{b}}$ values in the order of $10^{5}$, possibly due to quaternary nitrogen, which allows electrostatic interaction with the phosphate backbone of the DNA. However, increasing the molecular volume of the substituent directly bound to C9 decreases the interaction, it hinders the approach of the acridine nucleus to the DNA [33]. This fact justifies the lower $K_{b}$ values for the acridine derivative evaluated (1-4) due to C9 substitution with bulky groups (Scheme S1, compounds $\mathbf{i}$ and $\mathbf{j}$ ), although the compounds have a positive charge in the evaluated $\mathrm{pH}$ condition. In addition, the compounds $\mathbf{k}, \mathbf{1}$, and $\mathbf{m}$ (Scheme S1) are shown to have C9 substitution and $\mathrm{K}_{\mathrm{b}}$ values are on the order of $10^{3}$ and $10^{4}$. However, for the compounds assessed, in addition to C9 substitution, substituents at $\mathrm{C} 2$ and $\mathrm{C} 6$ positions are present. Thus, this set of factors may contribute to the decrease in $\mathrm{K}_{\mathrm{b}}$ value.

For the acridines derivatives evaluated in this work, the non-covalent binding constants $\left(\mathrm{K}_{\mathrm{b}}\right)$ followed the order $2>4>1>3$. Finally, based on Table 2 it was observed that, in general, the stoichiometric ratio value between acridines derivatives and ctDNA was close to the unit, indicating a molar ratio of $1: 1$. The values related to the thermodynamic parameter for $\Delta \mathrm{G}$ were all negative; in this case, the interaction process occurs spontaneously.

\subsubsection{Evaluation of the Compound-ctDNA Non-Covalent Binding Mode}

The non-covalent binding mode between acridine derivatives and ctDNA was evaluated through potassium iodide (KI) assay, fluorescence contact energy transfer study, competition assay with acridine orange (Fig. 2). Ethidium bromide (EB) was used as a competition probe since it has a well-established non-covalent binding mode (intercalation) and structural similarity with the compounds evaluated. Additionally, viscosity and thermal denaturation studies were performed for acridine derivative 2, which are presented in the Supplementary material.

2.3.2.1. Potassium Iodide Assay (KI). The potassium iodide assay is performed to evaluate the non-covalent binding mode between small molecules and DNA since it can promote dynamic quenching in fluorescent molecules if they are accessible to the iodide ion [34]. In this study, the comparison criteria used was the Stern-Volmer constant values in the presence and absence of ctDNA. The $\mathrm{K}_{\mathrm{SV}}$ values were calculated according to Eq. (1), where [Q] is the potassium iodide concentration. The Fig. 2a presents the results for this evaluation.

The $\mathrm{K}_{\mathrm{SV}}$ values for acridines derivatives 1,3 and 4 were systematically lower in the presence of ctDNA (Fig. 2a), indicating that the compounds are protected and the iodide ion had no access to them. Therefore, the non-covalent binding mode of these compounds with ctDNA preferably occurs via intercalation [22]. However, for acridine derivative $\mathbf{2}$ an inverse result was obtained, that is, the value of the Stern-Volmer constant was higher in the presence of ctDNA. The potassium iodide assay is subject to limitations since it evaluates only the protection degree of the ligands by the macromolecule [35]. Therefore, to confirm that $\mathbf{2}$ interacts through another DNA non-covalent binding mode, fluorescence contact energy transfer assay was performed.

2.3.2.2. Fluorescence Contact Energy Transfer. The fluorescence contact energy transfer assay is based on the energy transfer between a donor (ctDNA) and a receptor (acridine derivative) and is employed to elucidate the non-covalent binding mode of interaction with DNA through the minor groove, although behave as intercalators in other assays, and vice versa [36]. The fluorescence contact energy transfer assay employs the following equation:

$\frac{\mathrm{Q}_{\lambda}}{\mathrm{Q}_{310}}=\left(\frac{\mathrm{I}_{\lambda} \varepsilon_{310}}{\mathrm{I}_{310} \varepsilon_{\lambda}}\right)_{\text {bound }}\left(\frac{\mathrm{I}_{310} \varepsilon_{\lambda}}{\mathrm{I}_{\lambda} \varepsilon_{310}}\right)_{\text {free }}$

where I corresponds to the fluorescence intensity measured, $\varepsilon$ the molar extinction coefficient at a given wavelength $(\lambda)$ and at $310 \mathrm{~nm}$, and $Q$ refers to the quantum efficiency in each condition. The wavelength $310 \mathrm{~nm}$ was chosen for normalization since the absorbance of the DNA is negligible [37].

The energy transfer from the DNA bases to the ligand depends on many factors, such as spectral overlap, distance, and orientation of the dipoles. In this sense, when a compound interacts via intercalation, due to a shorter distance and overlapping of the planes ligand-DNA, and the energy can be transferred more efficiently than. The opposite profile occurs when the compound is bound to the outside of the macromolecule $[37,38]$.

In this analysis, acridine orange (intercalation) and berenil (minor groove) were used as models to compare the spectral profile obtained with acridine derivative 2 . The Fig. $2 \mathrm{~b}$ shows the acridine orange bound to ctDNA has high fluorescence intensity (excitation mode) around $260 \mathrm{~nm}$. This wavelength the ctDNA presents maximum absorbance, indicating that there was a strong energy transfer from ctDNA to the ligand. However, for berenil it was observed the ratio $Q_{\lambda} / Q_{310}<1$, suggesting that there was virtually no energy transfer. The spectral profile of acridine derivative $\mathbf{2}$ is similar to acridine orange, indicating that the preferential non-covalent binding mode with ctDNA is through intercalation.

2.3.2.3. Competition Assay with Ethidium Bromide (EB). Additionally, to corroborate the previous results, a competition assay with ethidium bromide (EB) was performed, which in its free form, shows low fluorescence emission (Fig. 2c), however, in the presence of DNA, a considerable increase in fluorescence intensity occurs due to the intercalation process [31]. Although acridine orange (AO, intercalator) is similar to the evaluated compounds, it could not be used as a competition probe due to the spectral overlap of the molecular absorption spectra of the acridine derivatives and the emission spectrum of the AO-ctDNA complex that can cause inner filter effect, and compromise the spectroscopic results (Fig. S19).

The presence of a ligand with the same DNA non-covalent binding mode as EB in the system can lead to displacement of the intercalated $\mathrm{EB}$, and consequently, a decrease in the fluorescence intensity, since part of the EB would be in the free form, (non-intercalated). The intensity of fluorescence emission of the EB-ctDNA complex decreased due to the concentration of the acridine derivatives increased. The maximum reduction obtained for the evaluated compounds was, 1 (39\%); 2 (46\%); 3 (37\%) and 4 (45\%). The magnitude of the signal reduction is directly related to the ability of the acridine derivatives evaluated by displacing the EB from DNA. Hence, it can be concluded that the non-covalent binding mode of the evaluated compounds occurs by similar way to $\mathrm{EB}$, corroborating with the results of the KI assay and fluorescence contact energy transfer, reinforcing the proposal of 

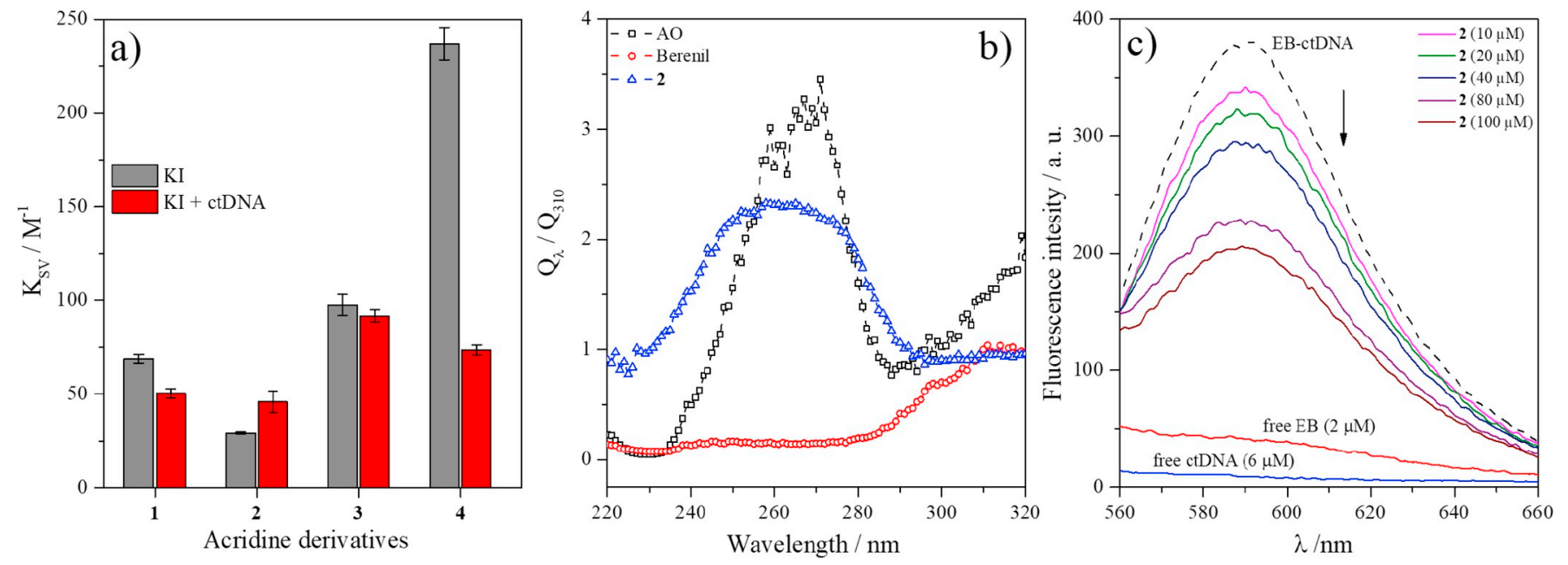

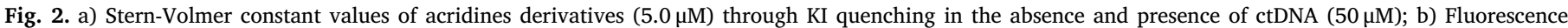

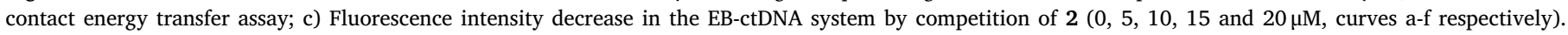
Condition: $\mathrm{pH}=7.4$ (phosphate buffer) at $30^{\circ} \mathrm{C}$ and $20 \mathrm{mM}$ of ionic strength.

acridine derivatives 1-4 interaction occurring preferably by intercalation with ctDNA. In addition, thermal denaturation and viscosity studies have shown that the preferred mode of binding between acridines and ctDNA occurs via intercalation.

\subsubsection{Correlation Analysis}

From the values of non-covalent binding constants $\left(\mathrm{K}_{\mathrm{b}}\right)$ the linear correlation was assessed with the $\mathrm{IC}_{50}$ values. This strategy was employed in order to observe whether these independent variables are related and therefore, if the mechanism of action of the acridine derivatives may be associated with the DNA interaction. The Fig. 3 shows the linear regression graph and the respective determination coefficient $\left(\mathrm{r}^{2}\right)$ obtained for the compounds evaluated against the chloroquine-resistant $P$. falciparum (W2) cell line with a 95\% confidence interval.

The antimalarial activity to all compounds evaluated was related with the non-covalent binding constant $\left(\mathrm{K}_{\mathrm{b}}\right)$, and an inverse trend was obtained with a coefficient of determination of 0.9535 (Fig. 3). This result agrees with some works of the literature. Mckeever et al. [39] evaluated the correlation of interaction with DNA and antiprotozoal

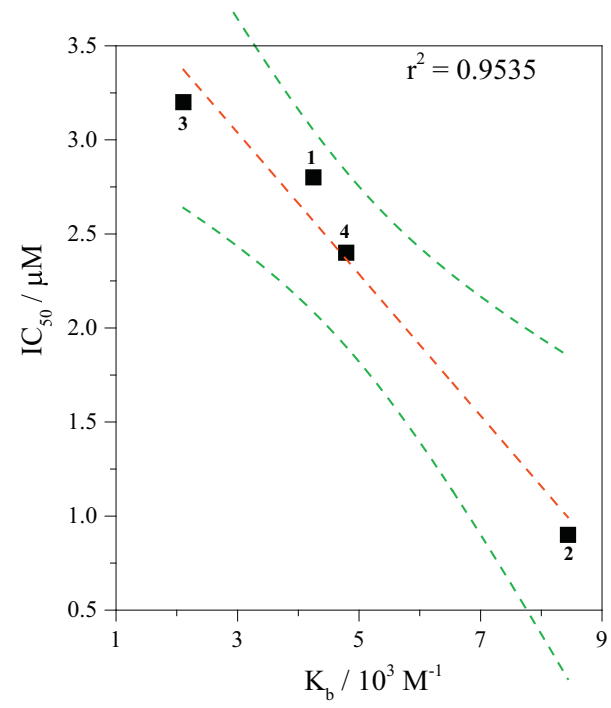

Fig. 3. Linear correlation of $\mathrm{IC}_{50}(\mu \mathrm{M})$ vs $\mathrm{K}_{\mathrm{b}}\left(\mathrm{M}^{-1}\right)$ at $95 \%$ confidence intervals (green lines). (For interpretation of the references to colour in this figure legend, the reader is referred to the web version of this article.) activity for diaromatic guanidine derivatives with $\mathrm{r}^{2}=0.87$. In a similar analysis, Rodríguez et al. [40] correlated anti-trypanosomal activity to bis(2-amino-imidazolin) derivatives with $\mathrm{K}_{\mathrm{b}}$ values for DNA interaction and obtained correlation coefficients ( $\mathrm{r}$ ) of 0.9056.

The acridine derivative $\mathbf{2}$ presented the highest non-covalent binding constant with ctDNA and obtained IC $_{50}$ values (for W2 cell line) similar to amsacrine (Tables 1 and 2). This result can be explained considering the structural similarity between the compounds, as well as the magnitude of the interaction between the amsacrine and the DNA, where the value of the binding constant $\left(\mathrm{K}_{\mathrm{b}}\right)$ reported was $1.2 \times 10^{4} \mathrm{M}^{-1}$ [25]. In addition, acridine derivative 2 demonstrated cytotoxic activity similar to primaquine, evidencing that this compound presents a good antimalarial activity.

The higher selectivity index indicates the compound is less toxic, and this way, is safer in the biological system. Thus, it can be verified that the acridine derivatives evaluated present SI comparable to primaquine and amsacrine, especially 2 , which presented higher selectivity index (Table 1). In addition, it was possible to observe that $\mathbf{2}$ exhibited cytotoxic activity ( $\mathrm{IC}_{50}-\mathrm{HepG}$ ) similar to primaquine. Therefore, the correlation results suggesting that the acridine derivatives assessed may have as their main biological target the DNA.

The subcellular localization of acridine derivatives is an important parameter for understanding the process of internalizing the compounds in cells. Considering works of the literature with compounds similar to those evaluated, which have bulky substituents in C9, it was possible to infer about the subcellular localization profile. Thus, Pereira et al. [41] and Carvalho et al. [42] evaluated the interaction of substituted acridine orange derivatives with C9 bulky groups and the compounds are internalized in the nucleus of the PC-3 and HeLa cells, respectively. Similarly, Esteves et al. [43] verified that new pyrazolyldiamine acridine derivatives target the nucleus of B16F1 murine melanoma cells, while Shiraishi et al. [44] found that bis- and trisacridines also have the ability to bind to nuclear DNA from JAR cells. Therefore, possibly the acridines derivatives (1-4) assessed have to target nuclear DNA.

\subsection{Interaction Studies with Human Serum Albumin (HSA)}

In order to understand the transport mechanism of the ligands, studies of the interaction with carrier proteins such as HSA are relevant. Therefore, it is necessary to investigate the main aspects that govern the interaction process and its relation to the distribution of the compounds under physiological simulated conditions [19]. 

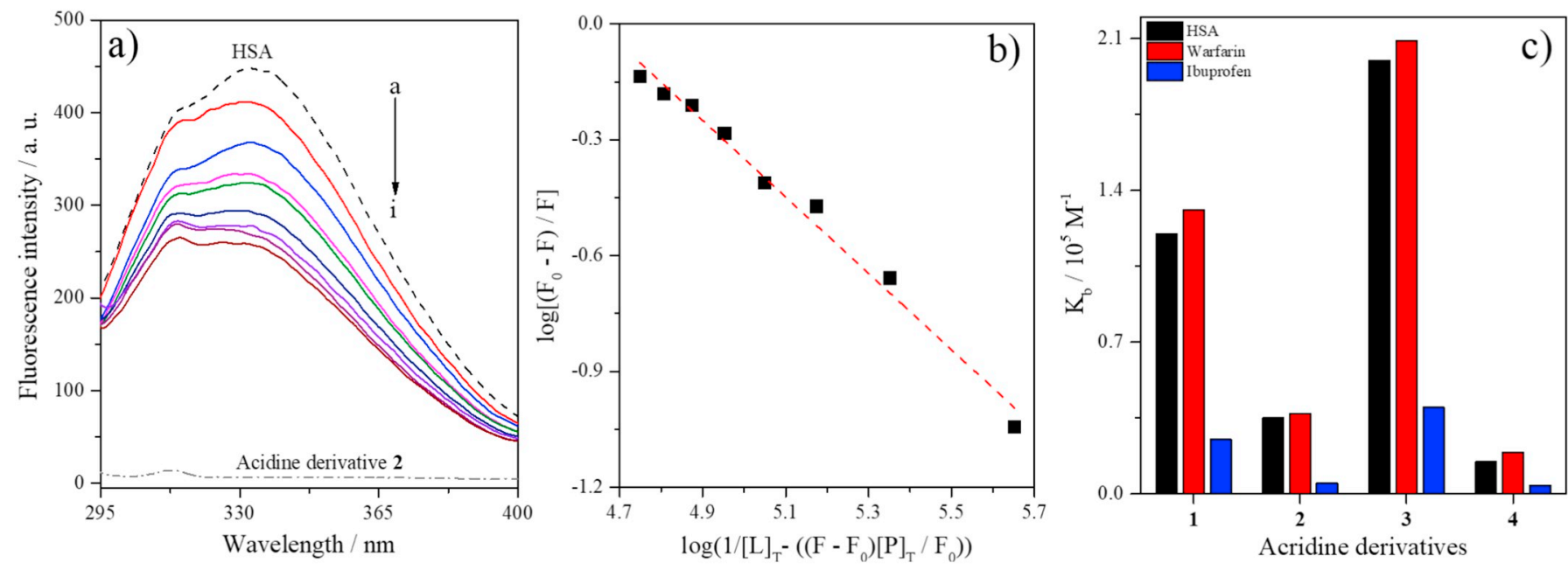

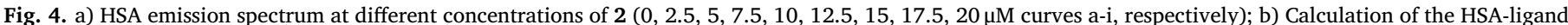

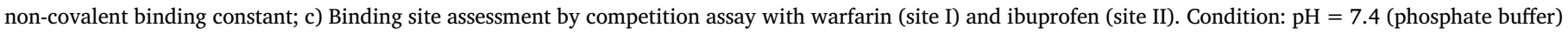
at $30{ }^{\circ} \mathrm{C}, 20 \mathrm{mM}$ ionic strength.

In the molecular fluorescence assays, it is observed that human serum albumin has a maximum emission band at $328 \mathrm{~nm}$ when excited at $280 \mathrm{~nm}$. When increasing amounts of the acridine derivatives are added, a gradual decrease of the fluorescence intensity of HSA is observed (Fig. 4a), indicating that these compounds bind to the protein, suppressing the protein intrinsic fluorescence. To evaluate the magnitude of the interaction, parameters such as the non-covalent binding constant $\left(\mathrm{K}_{\mathrm{b}}\right)$ and the number of binding sites $(n)$ were calculated, according to the Eq. (5):

$\log \left[\frac{\mathrm{F}_{0}-\mathrm{F}}{\mathrm{F}}\right]=n \log \mathrm{K}_{\mathrm{b}}-n \log \left(\frac{1}{[\mathrm{~L}]_{\mathrm{T}}-\left(\frac{\mathrm{F}_{0}-\mathrm{F}}{\mathrm{F}_{0}}\right)[P]_{T}}\right)$

where $\mathrm{F}_{0}$ and $\mathrm{F}$ are the fluorescence intensities of the protein in the presence and absence of the compound, respectively. $[\mathrm{L}]_{\mathrm{T}}$ is the total concentration of the acridine derivative (ligand) and $[\mathrm{P}]_{\mathrm{T}}$ is the total protein concentration. The linearization of this equation is presented in Fig. 4b. To evaluate the main non-covalent binding site of the acridine derivatives with HSA, competition assays were performed using warfarin and ibuprofen as site markers, which are well-established ligands for the site I and II, respectively [45].

Initially, by adding warfarin to the HSA solution, a shift towards longer wavelengths occurred as well as a decrease in fluorescence intensity related to the free HSA. Then, with the addition of $\mathbf{2}$ to the same system, the fluorescence intensity of the HSA-warfarin solution (1:1) gradually decreased. In contrast, with the addition of ibuprofen, there was no shift in the wavelength of the maximum emission intensity, and virtually no change was observed in the intrinsic fluorescence intensity of the HSA. However, similarly to warfarin, with the addition of acridines 1-4, the fluorescence intensity of the HSA-ibuprofen system (1:1) also decreased gradually. For a better comparison between the influence of warfarin and ibuprofen on the non-covalent binding of acridine derivatives with HSA, the $\mathrm{K}_{\mathrm{b}}$ for these systems were calculated (Fig. 4c).

The binding constants values for the acridines derivatives evaluated increased $(<5 \%)$ in the presence of warfarin, however, they significantly decreased in the presence of ibuprofen (Fig. 4c). The results suggest that the acridine derivatives 1-4 compete for the same binding site as ibuprofen, inferring that the compounds evaluated may bind preferentially to the site II of the HSA [46]. Additionally, the values of $n$ were approximately equal to unity, indicating that the stoichiometric ratio protein-acridine derivative is $1: 1$. In addition, it is worth mentioning that the values of the non-covalent binding constants obtained in this work corroborate with studies in the literature, which were performed with molecules structurally similar to the evaluated acridines and bovine serum albumin (BSA) [47-50]. However, there are no studies on competition assays with probes for acridine derivatives, although Mignot et al. [51] and Chen et al. [52] reported the study of bulky molecules against human serum albumin, which demonstrated site II as the preferred binding site.

Finally, it is worth highlighting the fact that the less active acridine derivatives ( 1 and 3 ) presented the highest values of $\mathrm{K}_{\mathrm{b}}$ with HSA (Fig. 4c), while the most active compounds ( 2 and 4 ) presented the least interaction with the protein. This means that the high affinity of these compounds with the carrier protein may affect their (bio)availability to the target system, influencing its therapeutic efficiency.

\subsection{Docking and TD-DFT Studies}

In order to obtain more accurate results, the molecular dynamic was employed to goal the native structure of the DNA at physiological conditions and molecular docking was carried out to understand the interaction mechanism and the preferred molecular orientation of acridine derivatives. The derivative without benzylidene group (1) presented the lowest non-covalent binding energy value, showing fewer interactions with the DNA in comparison with the others derivatives substituted with benzylidene group (2-4) (Table 3). The molecular docking poses are showing in Fig. 5a-b, and the most favorable binding conformation of the compound 4 is shown in Fig. 5c.

In general, all the ligand-DNA complexes were stabilized by many hydrophobic interactions. However, only for the acridine derivative 1, it was observed $\mathrm{H}$-bond involving the carbonyl group and the DT8 base.

Table 3

Comparative docking score, hydrophobic and H-bond interactions for each acridine derivative.

\begin{tabular}{|c|c|c|c|}
\hline \multirow[t]{2}{*}{ Compound } & \multicolumn{2}{|l|}{ Interactions } & \multirow{2}{*}{$\begin{array}{l}\text { Docking score } \\
\left(\mathrm{kcal} \mathrm{mol}^{-1}\right)\end{array}$} \\
\hline & Hydrophobic & H-bond (Å) & \\
\hline 1 & DT7 and DC9 & $\begin{array}{l}\text { DT8 with } \\
\text { carbonyl group }\end{array}$ & -6.7 \\
\hline 2 & $\begin{array}{l}\text { DA6, DT8, DC9, DA18 } \\
\text { and DT19 }\end{array}$ & - & -8.4 \\
\hline 3 & $\begin{array}{l}\text { DA6, DT8, DC9, DA18 } \\
\text { and DT19 }\end{array}$ & - & -8.5 \\
\hline 4 & $\begin{array}{l}\text { DA6, DT8, DC9, DA18, } \\
\text { DG16 and DT19 }\end{array}$ & - & -8.6 \\
\hline
\end{tabular}



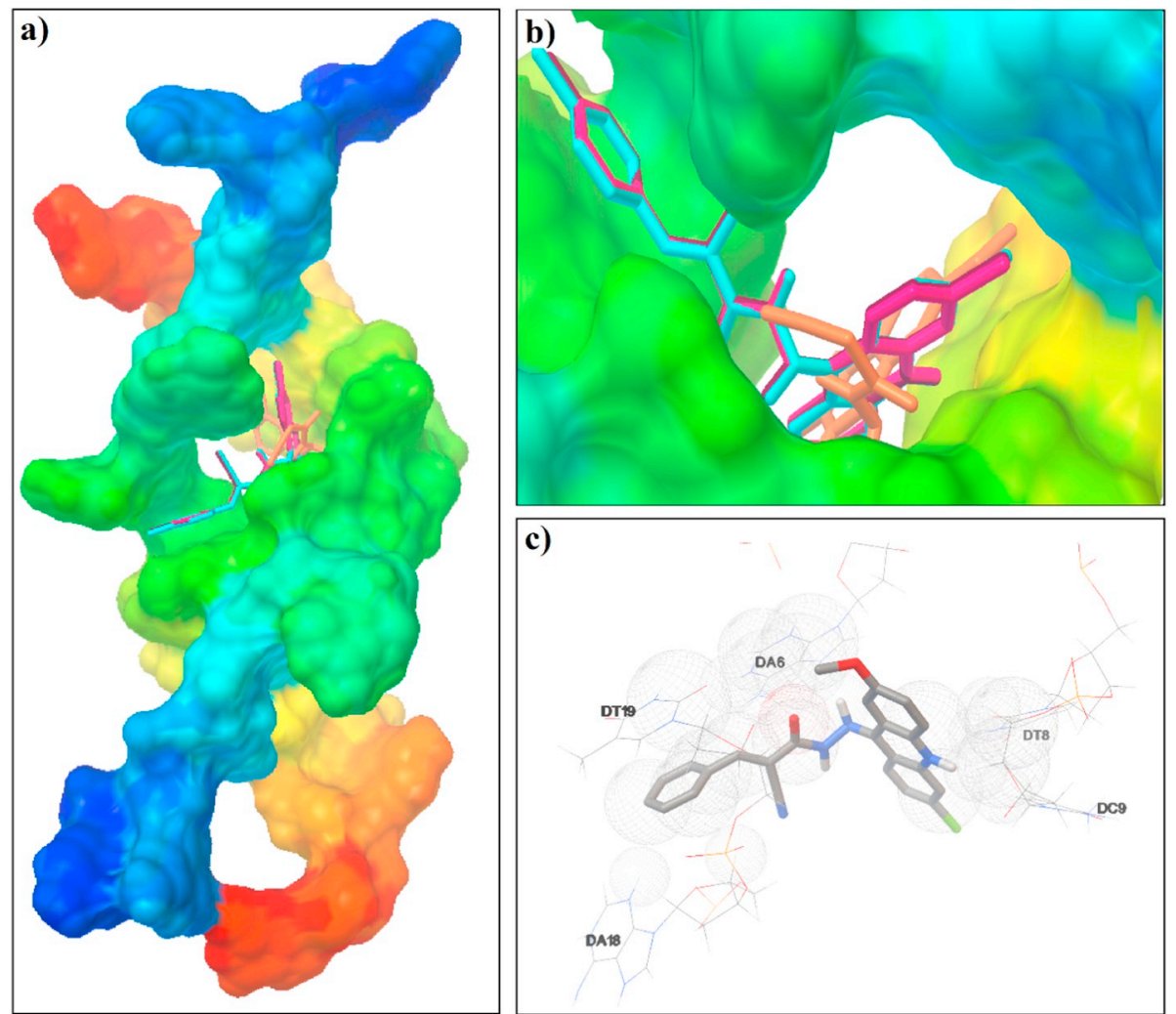

Fig. 5. a) and b) Molecular docking poses (clustering) of the acridine derivatives 1-4 in DNA generated by MD simulations (1 (orange), 2 (magenta), 3 (wine) e 4 (cyan), c) Molecular docked model of 2. Spheres: hydrophobic/close contacts.

Moreover, it is possible to observe overlap for the $2-4$ compounds. The acridine derivatives 2 and 4 have presented an RMSD value of $0.036 \AA$. This same value was also observed in the comparison of acridine derivatives $\mathbf{2}$ and $\mathbf{3}$. In contrast, a comparison of $\mathbf{3}$ and $\mathbf{4}$ showed an RMSD value of $0.02 \AA$. Based on these, the binding conformations suggest a plausible explanation for small energetic difference (binding energy in kcal $\mathrm{mol}^{-1}$ ) observed at the final results. It was noted that these compounds preferentially intercalate in the minor groove, as well as an act by partial intercalation modes, similarly to the observed results for acridine orange and others acridine derivatives [53]. For TD-DFT results, see supplementary material.

\section{Conclusion}

The acridine derivatives 1-4 evaluated in this work showed significant interaction with the DNA model employed, with the formation of a supramolecular complex. The $\mathrm{K}_{\mathrm{b}}$ values ranged from 2.09 to $7.76 \times 10^{3} \mathrm{M}^{-1}$, following the order of affinity: $2>4>1>3$. The preferential non-covalent binding mode of acridines derivatives with ctDNA was by intercalation. In the correlation analysis, an inverse trend was obtained, and the higher the $\mathrm{K}_{\mathrm{b}}$ with ctDNA the lower the $\mathrm{IC}_{50}$ value. The evaluated compounds were observed to possess an affinity with HSA, preferentially binding to the site II of the protein. Thus, from all results obtained by different techniques, it was possible to infer that the preferential mechanism of action of acridines 1-4 evaluated against antimalarial activity may be associated with interaction with DNA as the main biological target, and that the interaction with carrier proteins (such as HSA) may influence the activity of these derivatives. The acridine derivative $2\left(\mathrm{IC}_{50}=0.90 \pm 0.08 \mu \mathrm{M}\right)$ was more effective against $P$. falciparum than primaquine $\left(\mathrm{IC}_{50}=1.70 \pm 0.10 \mu \mathrm{M}\right)$ and similar to amsacrine $\left(\mathrm{IC}_{50}=0.80 \pm 0.10 \mu \mathrm{M}\right)$. Additionally, molecular docking results provide valuable information about binding energy and interaction modes of acridine derivatives with DNA model.

\section{Experimental}

\subsection{Synthesis}

TLC development was conducted on $0.25 \mathrm{~mm}$ silica gel plates $\left(60 \mathrm{~F}_{254}\right)$. The melting points were determined on QUIMIS 340 apparatus and are uncorrected. IR spectra were measured on BRUKER IFS66 FT-IR spectrophotometer. ${ }^{1} \mathrm{H}$ and ${ }^{13} \mathrm{C}$ NMR were recorded on Bruker AMX-300 MHz spectrometer. The chemical shifts are reported in $\delta$ units, multiplicities are given as s (singlet), d (doublet), t (triplet), $m$ (multiplet) and $d d$ (double doublet) and coupling constants $(J)$ are reported in Hertz. Mass spectra were recorded on matrix-assisted laser desorption/ionization recorded with a time-of-flight mass spectrometer (MALDI-TOF) Autoflex III (Bruker Daltonics, Billerica, MA, USA).

\subsubsection{Procedure for $N^{\prime}$-(6-chloro-2-methoxyacridin-9-yl)-2- Cyanoacetohydrazide (1)}

A solution of $0.01 \mathrm{~mol}$ of cyanoacethohydrazide and $0.01 \mathrm{~mol}$ of 6,9-dichloro-3-methoxyacridine in $50 \mathrm{~mL}$ of dried ethanol anhydrous was stirred at $70^{\circ} \mathrm{C}$ for $4 \mathrm{~h}$. After, the mixture was cooled to ambient temperature, and the precipitate was collected and washed with water. Finally, the product was purified by recrystallization from EtOH. Yellow powder; $\mathrm{mp} 270{ }^{\circ} \mathrm{C}$; Yield: 98\%; IR (KBr): $1628(\mathrm{NC}=\mathrm{O}), 1586$, 1506 and $1466(\mathrm{C}=\mathrm{C}, \mathrm{Ar}) ;{ }^{1} \mathrm{H}$ NMR $\left(300 \mathrm{MHz}, \mathrm{DMSO}-d_{6}\right): 12.11(\mathrm{~s}, 1 \mathrm{H}$, $\mathrm{NH}), 11.02$ (s, $1 \mathrm{H}, \mathrm{NH}), 8.77$ (d, $1 \mathrm{H}, J=9.6 \mathrm{~Hz}, \mathrm{Ar}-\mathrm{H}), 7.98-8.02(\mathrm{~m}$, $2 \mathrm{H}, \mathrm{Ar}-\mathrm{H}$ ), $7.93(\mathrm{~d}, 1 \mathrm{H}, J=9.3 \mathrm{~Hz}, \mathrm{Ar}-\mathrm{H}), 7.72(\mathrm{dd}, 1 \mathrm{H}, J=9.3$, $2.4 \mathrm{~Hz}, \mathrm{Ar}-\mathrm{H}$ ), 7.51 (d, $1 \mathrm{H}, J=7.8 \mathrm{~Hz}, \mathrm{Ar}-\mathrm{H}), 4.11\left(\mathrm{~s}, 2 \mathrm{H}, \mathrm{CH}_{2}\right), 3.93$ (s, $\left.3 \mathrm{H}, \mathrm{CH}_{3}\right) ;{ }^{13} \mathrm{C}$ NMR $\left(75.4 \mathrm{MHz}\right.$, DMSO- $\left.d_{6}\right): 24.14,56.18,115.26$, $117.48,120.61,124.17,127.57,134.89,138.85,139.85,153.09$, 155.90, 161.93. HRMS (ESI, electrospray ionization, $m / z$ ): Calculated for $\mathrm{C}_{17} \mathrm{H}_{13} \mathrm{ClN}_{4} \mathrm{O}_{2}$ 341.0727, Found: 341.0693 . 


\subsubsection{General Procedure for $2-4$}

To a solution of $0.0029 \mathrm{~mol}$ of $\mathbf{1}$ in dried toluene were added $0.0029 \mathrm{~mol}$ of required aromatic aldehyde and morpholine $(0.1 \mathrm{eq})$. The mixture was stirred at $110^{\circ} \mathrm{C}$ overnight. After, the mixture was cooled to ambient temperature, and the precipitate was collected and washed with ethanol. Finally, the product was purified by recrystallization from EtOH.

\subsection{3. $N^{\prime}$-(6-chloro-2-methoxyacridin-9-yl)-2-cyano-3-}

phenylacrylohydrazide (2)

Orange powder; mp $250-252^{\circ} \mathrm{C}$; Yield: 78\%; IR (KBr): 1633 (NC= O), $1607(\mathrm{C}=\mathrm{C}) ;{ }^{1} \mathrm{H}$ NMR $\left(300 \mathrm{MHz}\right.$, DMSO- $\left.d_{6}\right): 11.82(\mathrm{~s}, 1 \mathrm{H}, \mathrm{NH})$, $8.71(\mathrm{~s}, 1 \mathrm{H}, \mathrm{C}=\mathrm{CH}), 8.77(\mathrm{~d}, 1 \mathrm{H}, J=9.6 \mathrm{~Hz}, \mathrm{Ar}-\mathrm{H}), 7.98-8.02(\mathrm{~m}, 2 \mathrm{H}$, $\mathrm{Ar}-\mathrm{H}$ ), 7.93 (d, 1H, $J=9.3 \mathrm{~Hz}, \mathrm{Ar}-\mathrm{H}), 7.86-7.90(\mathrm{~m}, 2 \mathrm{H}, \mathrm{m}, \mathrm{Ar}-\mathrm{H})$, 7.72 (dd, $1 \mathrm{H}, J=9.3,2.6 \mathrm{~Hz}, \mathrm{Ar}-\mathrm{H}$ ), (m, $2 \mathrm{H}, \mathrm{m}, \mathrm{Ar}-\mathrm{H}$ ), 3.85 (s, $3 \mathrm{H}$, $\mathrm{CH}_{3}$ ); ${ }^{13} \mathrm{C}$ NMR $\left(75.4 \mathrm{MHz}\right.$, DMSO- $d_{6}$ ): $55.34,106.38,110.83,111.92$, $115.27,119.58,119.80,120.15,120.47,126.92,129.08,129.75$, 130.06 , 132.36, 134.50, 135.06. 139.58, 141.90, 142.44, 152.31, 154.43, 165.65. HRMS (ESI, $m / z$ ): Calculated for $\mathrm{C}_{23} \mathrm{H}_{14} \mathrm{ClN}_{4} \mathrm{O}$ 362.1157, Found: 362.1062.

\subsection{4. $N^{\prime}$-(6-chloro-2-methoxyacridin-9-yl)-2-cyano-3-(4-fluorophenyl) acrylohydrazide (3)}

Red powder; mp 209-210 ${ }^{\circ} \mathrm{C}$; Yield: 90\%; IR (KBr): 2353 (CN), 1632 $(\mathrm{NC}=\mathrm{O}), 1586$ and $1501(\mathrm{C}=\mathrm{C}), 1367(\mathrm{C}-\mathrm{F}) ;{ }^{1} \mathrm{H}$ NMR $(300 \mathrm{MHz}$, DMSO- $\left.d_{6}\right): 11.82(\mathrm{~s}, 1 \mathrm{H}, \mathrm{NH}), 8.71(\mathrm{~s}, 1 \mathrm{H}, \mathrm{C}=\mathrm{CH}), 8.21(\mathrm{~d}, 1 \mathrm{H}$, $J=9.0 \mathrm{~Hz}, \mathrm{Ar}-\mathrm{H}$ ), 7.90 (d, $1 \mathrm{H}, J=8.7 \mathrm{~Hz}, \mathrm{Ar}-\mathrm{H}), 7.60-7.61(\mathrm{~m}, 2 \mathrm{H}$, $\mathrm{m}, \mathrm{Ar}-\mathrm{H}), 7.55(\mathrm{~d}, 1 \mathrm{H}, J=8.4 \mathrm{~Hz}, \mathrm{Ar}-\mathrm{H}), 7.52(\mathrm{~d}, 1 \mathrm{H}, J=9.9 \mathrm{~Hz}$, $\mathrm{Ar}-\mathrm{H}), 7,42(\mathrm{~d}, 1 \mathrm{H}, J=9.6 \mathrm{~Hz}, \mathrm{Ar}-\mathrm{H}), 7.22(\mathrm{~d}, 1 \mathrm{H}, J=8.7 \mathrm{~Hz}, \mathrm{Ar}-\mathrm{H})$, 3.85 (s, $\left.3 \mathrm{H}, \mathrm{CH}_{3}\right) ;{ }^{13} \mathrm{C}$ NMR $\left(75.4 \mathrm{MHz}\right.$, DMSO- $d_{6}$ ): 55.39, 104.99, $101.60,106.81,115.27,116.21,119.29,121.09,121.25,124.50$, $128.32,129.09,130.01,132.10,135.62,137.61,141.07,146.70$, 150.40, 154.33, 165.90, 175.56. HRMS (ESI, $m / z$ ): Calculated for $\mathrm{C}_{24} \mathrm{H}_{16} \mathrm{ClFN}_{4} \mathrm{O}_{2}$ 446.0946, Found: 446.0996.

\subsection{5. $N^{\prime}$-(6-chloro-2-methoxyacridin-9-yl)-3-(4-chlorophenyl)-2- cyanoacrylohydrazide (4)}

Red powder; mp 212-213 ${ }^{\circ} \mathrm{C}$; Yield: 64\%; IR (KBr): $2353(\mathrm{CN}), 1633$ $(\mathrm{NC}=\mathrm{O}), 1597$ and $1567(\mathrm{C}=\mathrm{C}) ;{ }^{1} \mathrm{H}$ NMR $\left(300 \mathrm{MHz}, \mathrm{DMSO}-d_{6}\right): 11.82$ (s, $1 \mathrm{H}, \mathrm{NH}), 8.71(\mathrm{~s}, 1 \mathrm{H}, \mathrm{C}=\mathrm{CH}), 8.21(\mathrm{~d}, 1 \mathrm{H}, J=8.3 \mathrm{~Hz}, \mathrm{Ar}-\mathrm{H}), 7.89$ (d, $1 \mathrm{H}, J=11.7 \mathrm{~Hz}, \mathrm{Ar}-\mathrm{H}$ ), 7,46-7,60 (m, 5H, m, Ar-H), 7.42 (dd, 1H, $J=9.3,2.7 \mathrm{~Hz}, \mathrm{Ar}-\mathrm{H}$ ), 7.22 (dd, $1 \mathrm{H}, J=9.3,1.8 \mathrm{~Hz}, \mathrm{Ar}-\mathrm{H}$ ), 3.82 (s, $\left.3 \mathrm{H}, \mathrm{CH}_{3}\right) ;{ }^{13} \mathrm{C}$ NMR $\left(75.4 \mathrm{MHz}\right.$, DMSO- $\left.d_{6}\right)$ : 55.37, 99.65, 104.97, $101.60,104.97,115.27,116.19,119.27,121.05,121.25,124.48$, $128.30,129.07,129.98,132.56,135.58,135.96,141.05,146.70$, $150.40,154.33,160.56$. HRMS (ESI, $m / z$ ): Calculated for $\mathrm{C}_{23} \mathrm{H}_{13} \mathrm{ClN}_{4} \mathrm{O}$ 396.0767, Found: 396.0538 .

\subsection{Anti-P. Falciparum Activity}

W2 P. falciparum strain was maintained in continuous culture of human erythrocytes (blood group $\mathrm{O}^{+}$) using the RPMI 1640 medium supplemented with $10 \%$ of human plasma. Parasites grown at $1-2 \%$ parasitemia and $2.5 \%$ hematocrit were distributed into 96-well culture plate and incubated with the compounds (previously diluted with $4 \%$ (v/v) DMSO and culture medium). After $48 \mathrm{~h}$ of incubation, [3H]hypoxanthine was added, the plate incubated again and parasites were harvested using a cell harvester to quantify the [3H]hypoxanthine incorporation in a radiation counter. Inhibition of parasite growth was evaluated by comparison with [3H]hypoxanthine uptake in treated versus untreated parasite after $48 \mathrm{~h}$ of incubation. Each compound was initially tested at a concentration of $10 \mu \mathrm{M}$, in triplicate, and the $\mathrm{IC}_{50}$ values were calculated in triplicate concentration using at least five concentrations. Amsacrine, mefloquine, and primaquine were used as standard drugs.

\subsection{Cell Toxicity}

HepG2 cells were maintained in phenol red-free RPMI-1640 medium containing $10 \%$ fetal bovine serum and $50 \mu \mathrm{g} \mathrm{mL}^{-1}$ of gentamycin. Cells were seeded in 96-well plates $\left(10^{4}\right.$ cells/well in $100 \mu \mathrm{L}$ of medium). After $24 \mathrm{~h}$, compounds, previously diluted in RPMI- 1640 medium were added in five concentrations in triplicate and the plate incubated for $72 \mathrm{~h}$ at $37{ }^{\circ} \mathrm{C}$ and $5 \% \mathrm{CO}_{2}$. After this period, $20 \%$ of Alamar Blue was added to each well and the plate incubated for $24 \mathrm{~h}$. The absorbance at 570 and $600 \mathrm{~nm}$ was measured. Controls with untreated and treated cells were run in triplicates in the same plate.

\subsection{Interaction Acridine Derivatives 1-4 with ctDNA}

All reagents used were chemically pure. The solutions were prepared with ultrapure water with specific resistivity of $18.2 \mathrm{M} \Omega \mathrm{cm}$, from a Milli-Q ${ }^{\circledR}$ purification system (Millipore, Bedford, MA, USA). The DNA used was sodium salt of DNA Calf thymus type I (Sigma Aldrich, USA), prepared by dissolving an appropriate amount of ctDNA in phosphate buffer solution $(10 \mathrm{mM}, \mathrm{pH}=7.40 \pm 0.10)$ with $20 \mathrm{mM}$ of ionic strength and stored at $4{ }^{\circ} \mathrm{C}$. The phosphate buffer solution was prepared with $10 \%(\mathrm{v} / \mathrm{v})$ of DMSO to prevent precipitation of the acridines in the ctDNA interaction studies. The ctDNA concentration was determined by spectrophotometry $(\lambda=260 \mathrm{~nm})$, using molar extinction coefficient $\varepsilon_{260}=6600 \mathrm{~L} \mathrm{~mol}^{-1}$ at $30^{\circ} \mathrm{C}$. To assess the purity of ctDNA solution, the absorbance ratio at 260 and $280 \mathrm{~nm}\left(\mathrm{~A}_{260} / \mathrm{A}_{280}\right)$ was monitored, where a value between 1.8 and 1.9 indicates that the ctDNA solution was sufficiently free of proteins [25]. The solutions of the acridine derivatives 1-4 were prepared by dissolving an appropriate amount in DMSO with subsequent dilution in phosphate buffer. Under the conditions used in this work, no precipitation of acridines (1-4) was observed.

\subsubsection{UV-vis Absorption Measurements}

The spectrophotometric measurements were performed in a double beam spectrophotometer Micronal (AJX-6100PC model, Brazil) equipped with quartz cuvettes of $1.0 \mathrm{~cm}$ optical path. In this assay, the absorbance signal of the compound was evaluated in the absence and presence of ctDNA, as well as the absorbance of the ctDNA free. The concentration used was $10 \mu \mathrm{M}$ for compounds 1-4 and 25-100 $\mu \mathrm{M}$ for ctDNA. Then, spectrophotometric measurement was performed in the $360-580 \mathrm{~nm}$ range.

In the melting temperature DNA assays, the absorbance signal of the ctDNA samples $(50 \mu \mathrm{M})$ in the absence and presence of acridine derivative $2(50 \mu \mathrm{M})$ was monitored at $260 \mathrm{~nm}$, slowly heated from 35 to $100{ }^{\circ} \mathrm{C}$ using a heating system model SP12-200ED (SPlabor, Brazil) [31].

\subsubsection{Molecular Fluorescence Studies}

The spectrofluorometric titrations were performed using a spectrofluorometer Shimadzu RF (5301PC, Japan), equipped with a xenon lamp, using quartz cuvettes with $10 \mathrm{~mm}$ of the optical path. Spectrofluorometric titrations were performed by maintaining the concentration of the acridines derivatives at $10 \mu \mathrm{M}$, with the addition of increasing amounts of ctDNA, varying according to each compound. In general, the concentration range used for the acridines derivatives was $10-300 \mu \mathrm{M}$. After the incubation time $(30 \mathrm{~min})$, analytical measurements were performed at $30^{\circ} \mathrm{C}$.

In the evaluation of the interaction non-covalent binding mode between acridine derivatives 1-4 and ctDNA, the concentration of acridines $(5 \mu \mathrm{M})$ and the concentration of potassium iodide (5 to $150 \mathrm{mM}$ ) were maintained constant in the presence and absence of ctDNA $(50 \mu \mathrm{M})$. The evaluated compounds were excited between 280 and $295 \mathrm{~nm}$ and presented emission at $461 \mathrm{~nm}$, using slit 5-5 (for excitation and emission). In competition assays employing the probe ethidium bromide $\left(\mathrm{EB}, \lambda_{\mathrm{ex}}=525 \mathrm{~nm} / \lambda_{\mathrm{em}}=591 \mathrm{~nm}\right.$ ), a solution of EB at $2.0 \mu \mathrm{M}$ 
containing $6.0 \mu \mathrm{M}$ of ctDNA was employed. In the study of fluorescence contact energy transfer, excitation and absorption spectra of the evaluated compounds and the berenil and acridine orange probes were performed in the absence and presence of ctDNA, as well as free ctDNA from 200 to $350 \mathrm{~nm}$. The concentration of the compounds/probes and ctDNA was 10 and $100 \mu \mathrm{M}$, respectively.

\subsubsection{Viscosity Measurement}

The viscosity measurements were performed using a Cannon-Fenske viscosimeter (Model 50) immersed in a thermostatic bath at $37.0 \pm 0.2^{\circ} \mathrm{C}$. In this assay the ratio of acridine derivative 2 or the probes and ctDNA ranged from 0.25 to 1.0 , keeping the ctDNA concentration fixed at $100 \mu \mathrm{M}$. The analyzes were performed in duplicate and the time was measured using a digital chronometer with an accuracy of $0.1 \mathrm{~s}$. The results for this assay were presented in graphical form as $\left(\eta / \eta_{0}\right)^{1 / 3}$ vs [2 or probes]/[ctDNA], where $\eta$ and $\eta_{0}$ corresponds to the viscosity of the ctDNA solution in the presence and absence of acridine derivative $\mathbf{2}$, and the probes berenil or acridine orange.

\subsection{Interaction Acridine Derivatives 1-4 with HSA}

The stock solution of albumin from human serum (lyophilized powder, $\geq 96 \%)$ was prepared in phosphate buffer $(10 \mathrm{mM})$ at $\mathrm{pH} 7.2$. The phosphate buffer solution was prepared with $3 \%(v / v)$ of DMSO to prevent precipitation of the acridines HSA interaction studies. The concentration of HSA was set at $1.0 \mu \mathrm{M}$ in all assays, and subsequently increasing concentrations of the compounds 1-4 in the concentration range from 1 to $20 \mu \mathrm{M}$, were added. For the measurements it was used $\lambda_{\text {ex }}=280 \mathrm{~nm}$, using slit of $5 \mathrm{~nm}$ for excitation and emission at $30^{\circ} \mathrm{C}$. To evaluate the HSA preferential binding site between the acridine derivatives 1-4 and HSA, warfarin (site I) and ibuprofen (site II), were used as markers, where their stock solution was prepared in acetone and methanol, respectively. The concentration of these markers in all assays was $1.0 \mu \mathrm{M}$, establishing the 1:1 (HSA: marker) proportion.

\subsection{Docking and TD-DFT Studies}

The coordinates for building the molecular model were extracted from the X-ray crystal structure of the DNA dodecamer d(CGCGAATT CGCG) (PDB entry: 1BNA). All molecular dynamic proceeds were performed in agreement with Silva et al. [35]. The acridine derivatives 1-4 structures were drawn in SMILES format and converted into three-dimensional MOL2 files using Corina (Molecular Networks, http://www. molecular-networks.com/) [54]. Austin Model (AM1) was employed as an energy minimization method by ArgusLab v4.0.1 (http://www. arguslab.com/arguslab.com/ ArgusLab.html). The final structure was converted in pdbqt* format by AutoDock Tools v. 1.5.6 (http:// autodock.scripps.edu/ downloads). The acridine derivatives 1-4 were considered into pH 7.4 (physiological conditions). Finally, the protonation state was generated using the Fixpka from QuacPac v15.0 program (http://www.eyesopen.com/news/quacpac-v150-released). All ligands, ions and solvent molecules that were present in the DNA original structure downloaded from the Protein Data Bank (PDB) were manually removed, and hydrogen atoms were added using the graphical interface of AutoDock Tools v. 1.5.6. Blind-docking search was employed based on the possible groove mechanism. Finally, a grid box with centered coordinates on $x=1.389, y=-1.149$, and $z=-7.376 \AA$ was established on AutoDock Tools v. 1.5.6. The grid was used to evaluate the steric boundary of the DNA and Van der Waals and/or hydrogen bond interactions between the ligand and the macromolecule [55]. Partial atomic charges were added by using the Kollman mathematical method [56] and all atoms were assigned as AD4 type. Finally, the molecule was converted to pdbqt* extension [57]. For TD-DFT methodology, see Supplementary material.

\section{Author Contributions}

Synthesis and characterization of evaluated acridine derivatives: FJBMJ, ALCP, VLS, and ROM. Design and realization of ctDNA and HSA interaction experiments: IMF, JCCS, MMS, MDAD, EOON, and TMSM. Design and realization of biological assays: TSM, HMPT, DRMM, MBPS, and MCAL. Theoretical studies: EFSJ, JXAJ, and TMA. Wrote and revised the manuscript: TMA, IMF, and JCCS.

\section{Conflicts of Interest}

The authors declare that there is no conflict of interest.

\section{Acknowledgements}

Authors are thankful to the Instituto de Química e Biotecnologia (UFAL), Conselho Nacional de Desenvolvimento Científico e Tecnológico (CNPq), FAPEAL (Process number 60030 000863/2016), FAPESB, FAPESQ and FACEPE. This study was financed in part by the Coordenação de Aperfeiçoamento de Pessoal de Nível Superior - Brasil (CAPES) - Finance Code 001.

\section{Appendix A. Supplementary Data}

Supplementary data to this article can be found online at https:// doi.org/10.1016/j.jphotobiol.2018.10.016.

\section{References}

[1] R. Kumar, M. Kaur, M. Kumari, Acridine: a versatile heterocyclic nucleus, Acta Pol. Pharm. 69 (2012) 3-9.

[2] M.M. Patel, M.D. Mali, S.K. Patel, Bernthsen synthesis, antimicrobial activities and cytotoxicity of acridine derivatives, Bioorg. Med. Chem. Lett. 20 (2010) 6324-6326, https://doi.org/10.1016/j.bmcl.2010.06.001.

[3] G. Cholewiński, K. Dzierzbicka, A.M. Kołodziejczyk, Natural and synthetic acridines/acridones as antitumor agents: their biological activities and methods of synthesis, Pharmacol. Rep. 63 (2011) 305-336.

[4] W.A. Denny, Acridine derivatives as chemotherapeutic agents, Curr. Med. Chem. 9 (2002) 1655-1665, https://doi.org/10.2174/0929867023369277.

[5] M.O. Anderson, J. Sherrill, P.B. Madrid, A.P. Liou, J.L. Weisman, J.L. Derisi, R.K. Guy, Parallel synthesis of 9-aminoacridines and their evaluation against chloroquine-resistant Plasmodium falciparum, Bioorg. Med. Chem. 14 (2006) 334-343, https://doi.org/10.1016/j.bmc.2005.08.017.

[6] S.M. Sondhi, J. Singh, R. Rani, P.P. Gupta, S.K. Agrawal, A.K. Saxena, Synthesis, anti-inflammatory and anticancer activity evaluation of some novel acridine derivatives, Eur. J. Med. Chem. 45 (2010) 555-563, https://doi.org/10.1016/j.ejmech. 2009.10.042.

[7] S.P. Prajapati, N.K. Kaushik, M. Zaveri, D. Mohanakrishanan, N. Kawathekar, D. Sahal, Synthesis, characterization and antimalarial evaluation of new $\beta$-benzoylstyrene derivatives of acridine, Arab. J. Chem. 10 (2017) S274-S280, https:// doi.org/10.1016/j.arabjc.2012.07.033.

[8] V. Tomar, G. Bhattacharjee, null Kamaluddin, S. Rajakumar, K. Srivastava, S.K. Puri, Synthesis of new chalcone derivatives containing acridinyl moiety with potential antimalarial activity, Eur. J. Med. Chem. 45 (2010) 745-751, https://doi. org/10.1016/j.ejmech.2009.11.022.

[9] C. Di Giorgio, Y. Benchabane, G. Boyer, P. Piccerelle, M. De Méo, Evaluation of the mutagenic/clastogenic potential of 3,6-di-substituted acridines targeted for anticancer chemotherapy, Food Chem. Toxicol. 49 (2011) 2773-2779, https://doi.org/ 10.1016/j.fct.2011.07.046.

[10] J. Joseph, E. Kuruvilla, A.T. Achuthan, D. Ramaiah, G.B. Schuster, Tuning of intercalation and electron-transfer processes between DNA and acridinium derivatives through steric effects, Bioconjug. Chem. 15 (2004) 1230-1235, https://doi. org/10.1021/bc0498222.

[11] S. Auparakkitanon, W. Noonpakdee, R.K. Ralph, W.A. Denny, P. Wilairat, Antimalarial 9-anilinoacridine compounds directed at hematin, Antimicrob. Agents Chemother. 47 (2003) 3708-3712, https://doi.org/10.1128/AAC.47.12.37083712.2003.

[12] P. Chavalitshewinkoon-Petmitr, G. Pongvilairat, R.K. Ralph, W.A. Denny, P. Wilairat, Inhibitory effects of 9-anilinoacridines on Plasmodium falciparum gametocytes, Tropical Med. Int. Health 6 (2001) 42-45, https://doi.org/10.1046/j. 1365-3156.2001.00656.x.

[13] S.A. Gamage, N. Tepsiri, P. Wilairat, S.J. Wojcik, D.P. Figgitt, R.K. Ralph, W.A. Denny, Synthesis and in vitro evaluation of 9-anilino-3,6-diaminoacridines active against a multidrug-resistant strain of the malaria parasite Plasmodium falciparum, J. Med. Chem. 37 (1994) 1486-1494, https://doi.org/10.1021/ jm00036a014.

[14] F.J.B.M. Junior, T.M. Aquino, Doenças negligenciadas sob a ótica da Química 
Medicinal, 1st ed., Editora CRV, 2015, https://doi.org/10.24824/978854440508.6.

[15] J. Wiesner, R. Ortmann, H. Jomaa, M. Schlitzer, New antimalarial drugs, Angew. Chem. Int. Ed. 42 (2003) 5274-5293, https://doi.org/10.1002/anie.200200569.

[16] T.T. Diagana, Supporting malaria elimination with 21st century antimalarial agent drug discovery, Drug Discov. Today 20 (2015) 1265-1270, https://doi.org/10. 1016/j.drudis.2015.06.009.

[17] J. Janočková, J. Plšíková, J. Kašpárková, V. Brabec, R. Jendželovský, J. Mikeš, J. Koval', S. Hamulaková, P. Fedoročko, K. Kuča, M. Kožurková, Inhibition of DNA topoisomerases I and II and growth inhibition of HL-60 cells by novel acridinebased compounds, Eur. J. Pharm. Sci. 76 (2015) 192-202, https://doi.org/10. 1016/j.ejps.2015.04.023.

[18] S. Nafisi, A. Panahyab, G. Bagheri Sadeghi, Interactions between $\beta$-carboline alkaloids and bovine serum albumin: investigation by spectroscopic approach, J. Lumin. 132 (2012) 2361-2366, https://doi.org/10.1016/j.jlumin.2012.03.075.

[19] A.F.-C. Valdés, Acridine and Acridinones: old and new structures with antimalarial activity, Open Med. Chem. J. 5 (2011) 11-20, https://doi.org/10.2174/ 1874104501105010011.

[20] J.-H. Shi, T.-T. Liu, M. Jiang, J. Chen, Q. Wang, Characterization of interaction of calf thymus DNA with gefitinib: spectroscopic methods and molecular docking, J. Photochem. Photobiol. B 147 (2015) 47-55, https://doi.org/10.1016/j.jphotobiol. 2015.03.005.

[21] S. Das, C.J. Silva, M.M. Silva, M.D.A. Dantas, A. de Fátima, A.L.T.G. Ruiz, C.M. Silva, J.E. Carvalho, J.C.C. Santos, I.M. Figueiredo, E.F. Silva-Júnior, T.M. Aquino, J.X. Araújo-Júnior, G. Brahmachari, L.V. Modolo, Highly functionalized piperidines: free radical scavenging, anticancer activity, DNA interaction and correlation with biological activity, J. Adv. Res. 9 (2018) 51-61, https://doi.org/ 10.1016/j.jare.2017.10.010.

[22] F.C. Savariz, M.A. Foglio, A.L.T.G. Ruiz, W.F. da Costa, M.M. Silva, J.C.C. Santos, I.M. Figueiredo, E. Meyer, J.E. de Carvalho, M.H. Sarragiotto, Synthesis and antitumor activity of novel 1-substituted phenyl 3-(2-oxo-1,3,4-oxadiazol-5-yl) $\beta$-carbolines and their Mannich bases, Bioorg. Med. Chem. 22 (2014) 6867-6875, https://doi.org/10.1016/j.bmc.2014.10.031.

[23] C. Gao, B. Li, B. Zhang, Q. Sun, L. Li, X. Li, C. Chen, C. Tan, H. Liu, Y. Jiang, Synthesis and biological evaluation of benzimidazole acridine derivatives as potential DNA-binding and apoptosis-inducing agents, Bioorg. Med. Chem. 23 (2015) 1800-1807, https://doi.org/10.1016/j.bmc.2015.02.036.

[24] J.H. Kwon, H.-J. Park, N. Chitrapriya, S.W. Han, G.J. Lee, D.J. Lee, T.-S. Cho, Effect of number and location of amine groups on the thermodynamic parameters on the acridine derivatives to DNA, Bull. Kor. Chem. Soc. 34 (2013) 810-814, https://doi. org/10.5012/bkcs.2013.34.3.810.

[25] D.K. Jangir, S.K. Dey, S. Kundu, R. Mehrotra, Assessment of amsacrine binding with DNA using UV-visible, circular dichroism and Raman spectroscopic techniques, J. Photochem. Photobiol. B 114 (2012) 38-43, https://doi.org/10.1016/j.jphotobiol. 2012.05.005.

[26] J. Plsikova, L. Janovec, J. Koval, J. Ungvarsky, J. Mikes, R. Jendzelovsky, P. Fedorocko, J. Imrich, P. Kristian, J. Kasparkova, V. Brabec, M. Kozurkova, 3,6-Bis (3-alkylguanidino)acridines as DNA-intercalating antitumor agents, Eur. J. Med. Chem. 57 (2012) 283-295, https://doi.org/10.1016/j.ejmech.2012.09.020.

[27] M. Wu, W. Wu, X. Gao, X. Lin, Z. Xie, Synthesis of a novel fluorescent probe based on acridine skeleton used for sensitive determination of DNA, Talanta 75 (2008) 995-1001, https://doi.org/10.1016/j.talanta.2007.12.039.

[28] L. Janovec, D. Sabolova, M. Kozurkova, H. Paulíkova, P. Kristian, J. Ungvarský, E. Moravcíkova, M. Bajdichova, D. Podhradský, J. Imrich, Synthesis, DNA interaction, and cytotoxic activity of a novel proflavine-dithiazolidinone pharmacophore, Bioconjug. Chem. 18 (2007) 93-100, https://doi.org/10.1021/bc060168v.

[29] O.M. Salem, M. Vilková, J. Janočková, R. Jendželovský, P. Fedoročko, E. Žilecká, J. Kašpárková, V. Brabec, J. Imrich, M. Kožurková, New spiro tria(thia)zolidineacridines as topoisomerase inhibitors, DNA binders and cytostatic compounds, Int. J. Biol. Macromol. 86 (2016) 690-700, https://doi.org/10.1016/j.ijbiomac.2016. 02.018 .

[30] S.M.V. de Almeida, E.A. Lafayette, W.L. Silva, V. de Lima Serafim, T.M. Menezes, J.L. Neves, A.L.T.G. Ruiz, J.E. de Carvalho, R.O. de Moura, E.I.C. Beltrão, L.B. de Carvalho Júnior, M. do C.A. de Lima, New spiro-acridines: DNA interaction, antiproliferative activity and inhibition of human DNA topoisomerases, Int. J. Biol. Macromol. 92 (2016) 467-475, https://doi.org/10.1016/j.ijbiomac.2016.07.057.

[31] M.M. Silva, F.C. Savariz, E.F. Silva-Júnior, T.M. de Aquino, M.H. Sarragiotto, J.C.C. Santos, I.M. Figueiredo, Interaction of $\beta$-carbolines with DNA: spectroscopic studies, correlation with biological activity and molecular docking, J. Braz. Chem. Soc. 27 (2016) 1558-1568, https://doi.org/10.5935/0103-5053.20160035.

[32] ChemAxon, Marvin n.n.n version 18.04, 201n, http://www.chemaxon.com, (2018) (accessed 02 July 2018).

[33] A.M. Pizarro, P.J. Sadler, Unusual DNA binding modes for metal anticancer complexes, Biochimie 91 (2009) 1198-1211, https://doi.org/10.1016/j.biochi.2009. 03.017.

[34] A.R.O. Rodrigues, M.S.D. Carvalho, J.A.V. Cardoso, R.C. Calhelha, M.J.R.P. Queiroz, P.J.G. Coutinho, E.M.S. Castanheira, Benzothienoquinolines: new one-pot synthesis and fluorescence studies of their interaction with DNA and polynucleotides, J. Photochem. Photobiol. A Chem. 294 (2014) 20-30, https://doi. org/10.1016/j.jphotochem.2014.08.001.

[35] M.M. Silva, E.O.O. Nascimento, E.F. Silva-Júnior, J.X. Araújo-Júnior, C.C. Santana, L.A.M. Grillo, R.S. De Oliveira, P.R.R. Costa, C.D. Buarque, J.C. Santos, I.M. Figueiredo, Interaction between bioactive compound 11a-N-tosyl-5-deoxi- pterocarpan (LQB-223) and Calf thymus DNA: spectroscopic approach, electrophoresis and theoretical studies, Int. J. Biol. Macromol. 96 (2017) 223-233, https:// doi.org/10.1016/j.ijbiomac.2016.12.044.

[36] D. Suh, Environments of ethidium binding to allosteric DNA: II. Accessibility, mobility and mode of binding, Exp. Mol. Med. 32 (2000) 204-209, https://doi.org/10. 1038/emm.2000.33.

[37] D. Suh, J.B. Chaires, Criteria for the mode of binding of DNA binding agents, Bioorg. Med. Chem. 3 (1995) 723-728, https://doi.org/10.1016/0968-0896(95)00053-J.

[38] K.-M. Hyun, S.-D. Choi, S. Lee, S.K. Kim, Can energy transfer be an indicator for DNA intercalation? Biochim. Biophys. Acta Gen. Subj. 1334 (1997) 312-316, https://doi.org/10.1016/S0304-4165(96)00111-0.

[39] C. McKeever, M. Kaiser, I. Rozas, Aminoalkyl Derivatives of Guanidine Diaromatic Minor Groove Binders with Antiprotozoal activity, J. Med. Chem. 56 (2013) 700-711, https://doi.org/10.1021/jm301614w.

[40] F. Rodríguez, I. Rozas, M. Kaiser, R. Brun, B. Nguyen, W.D. Wilson, R.N. García, C. Dardonville, New bis(2-aminoimidazoline) and bisguanidine DNA minor groove binders with potent in vivo antitrypanosomal and antiplasmodial activity, J. Med. Chem. 51 (2008) 909-923, https://doi.org/10.1021/jm7013088.

[41] E. Pereira, L. Quental, E. Palma, M.C. Oliveira, F. Mendes, P. Raposinho, I. Correia, J. Lavrado, S. Di Maria, A. Belchior, P. Vaz, I. Santos, A. Paulo, Evaluation of acridine orange derivatives as DNA-targeted radiopharmaceuticals for Auger therapy: influence of the radionuclide and distance to DNA, Sci. Rep. 7 (2017) 1-16, https:// doi.org/10.1038/srep42544.

[42] J. Carvalho, E. Pereira, J. Marquevielle, M.P.C. Campello, J.L. Mergny, A. Paulo, G.F. Salgado, J.A. Queiroz, C. Cruz, Fluorescent light-up acridine orange derivatives bind and stabilize KRAS-22RT G-quadruplex, Biochimie 144 (2018) 144-152, https://doi.org/10.1016/j.biochi.2017.11.004.

[43] T. Esteves, C. Xavier, S. Gama, F. Mendes, P.D. Raposinho, F. Marques, A. Paulo, J.C. Pessoa, J. Rino, G. Viola, I. Santos, Tricarbonyl M(I) (M = Re, 99mTc) complexes bearing acridine fluorophores: synthesis, characterization, DNA interaction studies and nuclear targeting, Org. Biomol. Chem. 8 (2010) 4104-4116, https://doi. org/10.1039/c0ob00073f.

[44] T. Shiraishi, R. Hamzavi, P.E. Nielsen, Targeted delivery of plasmid DNA into the nucleus of cells via nuclear localization signal peptide conjugated to DNA intercalating bis-and trisacridines, Bioconjug. Chem. 16 (2005) 1112-1116, https://doi. org/10.1021/bc050093f.

[45] G. Zhang, Y. Ma, Mechanistic and conformational studies on the interaction of food dye amaranth with human serum albumin by multispectroscopic methods, Food Chem. 136 (2013) 442-449, https://doi.org/10.1016/j.foodchem.2012.09.026.

[46] Z. Fu, Y. Cui, F. Cui, G. Zhang, Modeling techniques and fluorescence imaging investigation of the interactions of an anthraquinone derivative with HSA and ctDNA, Spectrochim. Acta A Mol. Biomol. Spectrosc. 153 (2016) 572-579, https://doi.org/ 10.1016/j.saa.2015.09.011.

[47] J. Wang, Y. Guo, B. Liu, C. Cheng, Z. Wang, G. Han, J. Gao, X. Zhang, Spectroscopic analyses on interaction of bovine serum albumin (BSA) with toluidine blue (TB) and its sonodynamic damage under ultrasonic irradiation, J. Lumin. 131 (2011) 231-237, https://doi.org/10.1016/j.jlumin.2010.10.003.

[48] A. Selva Sharma, S. Anandakumar, M. Ilanchelian, A combined spectroscopic and molecular docking study on site selective binding interaction of Toluidine blue $\mathrm{O}$ with Human and Bovine serum albumins, J. Lumin. 151 (2014) 206-218, https:// doi.org/10.1016/j.jlumin.2014.02.009.

[49] J. Wang, Y.-Y. Zhang, Y. Guo, L. Zhang, R. Xu, Z.-Q. Xing, S.-X. Wang, X.-D. Zhang, Interaction of bovine serum albumin with acridine orange (C.I. Basic Orange 14) and its sonodynamic damage under ultrasonic irradiation, Dyes Pigments 80 (2009) 271-278, https://doi.org/10.1016/j.dyepig.2008.07.013.

[50] D. Chen, J. Xie, Q. Wu, P. Fan, J. Wang, Interaction and sonodynamic damage activity of acridine red (AD-R) to bovine serum albumin (BSA), J. Lumin. 160 (2015) 245-253, https://doi.org/10.1016/j.jlumin.2014.12.021.

[51] I. Mignot, N. Presle, F. Lapicque, C. Monot, R. Dropsy, P. Netter, Albumin binding sites for etodolac enantiomers, Chirality 8 (1996) 271-280, https://doi.org/10. 1002/(SICI)1520-636X(1996)8:3 < 271::AID-CHIR7 > 3.0.CO;2-K.

[52] Z. Chen, H. Xu, Y. Zhu, J. Liu, K. Wang, P. Wang, S. Shang, X. Yi, Z. Wang, W. Shao, S. Zhang, Understanding the fate of an anesthetic, nalorphine upon interaction with human serum albumin: a photophysical and mass-spectroscopy approach, RSC Adv. 4 (2014) 25410-25419, https://doi.org/10.1039/C4RA03541K.

[53] C. Sengupta, S. Basu, A spectroscopic study to decipher the mode of interaction of some common acridine derivatives with CT DNA within nanosecond and femtosecond time domains, RSC Adv. 5 (2015) 78160-78171, https://doi.org/10.1039/ C5RA13035B.

[54] V.Y. Martiny, F. Martz, E. Selwa, B.I. Iorga, Blind pose prediction, scoring, and affinity ranking of the CSAR 2014 dataset, J. Chem. Inf. Model. (2015), https://doi. org/10.1021/acs.jcim.5b00337 151001125645007.

[55] X. Du, E. Hansell, J.C. Engel, C.R. Caffrey, F.E. Cohen, J.H. McKerrow, Aryl ureas represent a new class of anti-trypanosomal agents, Chem. Biol. 7 (2000) 733-742, https://doi.org/10.1016/S1074-5521(00)00018-1.

[56] J. Correa-Basurto, C. Flores-Sandoval, J. Marín-Cruz, A. Rojo-Domínguez, L.M. Espinoza-Fonseca, J.G. Trujillo-Ferrara, Docking and quantum mechanic studies on cholinesterases and their inhibitors, Eur. J. Med. Chem. 42 (2007) 10-19, https://doi.org/10.1016/j.ejmech.2006.08.015.

[57] X. Chen, QSAR and primary docking studies of trans-stilbene (TSB) series of imaging agents for $\beta$-amyloid plaques, J. Mol. Struct. THEOCHEM 763 (2006) 83-89, https://doi.org/10.1016/j.theochem.2006.01.028. 